\title{
РЕЛИГИОВЕДЕНИЕ
}

\author{
UDC $211.5+266$
}

\section{A comparison of the missionary method and cultural integration of Jesuits: A study in China and Vietnam during the $16^{\text {th }}$ and $17^{\text {th }}$ centuries}

\author{
Truong Anh Thuan, Nguyen Van Sang \\ The University of Danang, Unversity of Science and Education, \\ 459, Ton Duc Thang st., Da Nang, 550000, Vietnam
}

For citation: Truong Anh Thuan, Nguyen Van Sang. A comparison of the missionary method and cultural integration of Jesuits: A study in China and Vietnam during the $16^{\text {th }}$ and $17^{\text {th }}$ centuries. Vestnik of Saint Petersburg University. Philosophy and Conflict Studies, 2020, vol. 36, issue 2, pp. 407-421. https://doi.org/10.21638/spbu17.2020.216

From the end of the $16^{\text {th }}$ century to the beginning of the $17^{\text {th }}$ century, under the direction of the archdiocese in Macao (China), Jesuit missionaries set foot in China and Vietnam in turn to preach the Gospel and convert believers in these two countries. The main reason for the success of the Jesuits was the use of appropriate missionary methods and advocating proper cultural integration in each country. However, due to the different paradigm of historical development in China and Vietnam, and especially due to disagreement about the perception and behavior of indigenous culture among the Jesuits themselves, the process of evangelization in the two countries occurred differently. Based on historical and logical methods, especially the comparative method, this study analyzes and compares the similarities and differences in missionary methods and the advocacy of cultural integration in the two countries mentioned above. Primary sources were the foundation of the work, such as archival records and recently published research results of Chinese and Vietnamese scholars as well as other researchers. The results of this work contribute to assessing the similarities and differences in the process of applying missionary methods and cultural integration. The work further contributes to the study of Christian history in China and Vietnam in the $16^{\text {th }}$ and $17^{\text {th }}$ centuries.

Keywords: China, Vietnam, Jesuits, Christian, cultural integration.

\section{Introduction}

The $16^{\text {th }}$ and $17^{\text {th }}$ centuries were a time when Christianity was introduced and developed fervently in China as well as in Vietnam. This process in each country is always associated with the great role of Jesuit missionaries. In fact, Jesuits operated in China and

(c) Санкт-Петербургский государственный университет, 2020 
Vietnam at the same time and utilized a missionary method that can be referred to as "missionary academic" [1, p. 74-75; 2, p. 130-135] ${ }^{1}$. However, the level of expression and effectiveness that this method brought to each country was not the same. In particular during this period, the Jesuits internally in China and Vietnam debated and were divided on the views between the clergies with a progressive priesthood and supporting the local parishioners to preserve and practice traditional rituals and on the other hand, those who were extremist, narrow-minded missioners and prohibited indigenous rituals. This affected, to some extent, the results of the congregation's preaching of the Gospel in China and Vietnam in the $16^{\text {th }}-17^{\text {th }}$ centuries.

\section{The "missionary academic" method and its application by Jesuits in Vietnam and China}

In the first half of the $16^{\text {th }}$ century, the mission in China came to a standstill. Western clergies, despite all means, could not penetrate into the Chinese mainland to proclaim the Gospel. At that time, among the Christian congregations in Macao there was a fierce debate about choosing one of two methods: "missionary force" [3, p. 16-17; 4, p. 231 $]^{2}$ or "missionary academic" [1, p. 74]. However, in the second half of the 16th century, Western clergies initially succeeded in applying "adaptation to native culture" [5, p. 142-143] ${ }^{3}$ by Alessandro Valignano $[6 ; 7, \text { p. 336-351 }]^{4}$. This approach emphasizes the importance of acquiring cultural and historical values, customs and habits, especially learning and using the language and script of the missionary fluently for success in the proclamation of the Gospel. As a result, Matteo Ricci $[8-10]^{5}$ and other Jesuits gradually achieved the goal of opening up the door to the mainland of China to "cultivate" the first Christian "seeds". In the process, they realized that the most effective way to attract Chinese people,

${ }^{1}$ Missionary academic (学术 传教) is a term used by Chinese researchers only for the Jesuits using Western cultural and scientific achievements such as astronomy and geography, physics, mathematics, chemistry, military, art, and literature to attract strata in Chinese society, especially the upper classes to the Christian faith in the 16th and $17^{\text {th }}$ centuries. According to scholar Shi Jing Huan (史靜寰), the initiator of this mission was Francois Xavier, the Jesuit missionary of the Far East in the first half of the $16^{\text {th }}$ century. From the end of the $16^{\text {th }}$ century to the beginning of the $17^{\text {th }}$ century, the "academic missionary" method continued to be implemented by the Jesuits, typically Matteo Ricci, Michele Ruggleri and applied thoroughly, making the propaganda work of Christianity in China achieve great achievements [1, p. 74-75; 2, p. 130-135].

${ }^{2}$ From 1565 to 1569 , when the infiltration of Chinese missionaries was difficult, some Western missionaries such as Ribera, Melchior Nunes Barreto, Alonso Sanchez said that it was necessary to use force to open China for Christian entry. This idea marked the birth of the "missionary force" policy [3, p. 16-17; 4, p.231].

${ }^{3}$ In the strategy of adapting to the indigenous culture, Valignano missioners clearly pointed out that in order to conquer the faith of indigenous inhabitants, there was no other way to truly comprehend the cultural and historical values, customs and practices present, especially to learn and write fluently in the language of that nation. At the same time, he considered it as a magic key to expand the door and "Christianize" the Far East nations [5, p. 142-143].

${ }^{4}$ Alessandro Valignano (1539-1606) was a Jesuit missionary and an Italian. In his mission, Valignano mainly operated missionary in the Far East, especially Goa (India), Macau (China), and Japan [6; 7, p. 336$351]$.

${ }^{5}$ Mateo Ricci (1552-1610) was an Italian Jesuit who laid the foundations for the Jesuit missionary missions in China. He served as a Christian archbishop in China from 1597 to 1610. From 1582, he began to learn Chinese and Chinese culture. He was known as the Westerner who understood Chinese culture in the $16^{\text {th }}$ century $[8-10]$. 
especially the class of mandarins who believe in Christianity, was to use academic thought and achievements, Western scientific and technical knowledge to conquer faith [11, p.32]. Here, the "missionary academic" formally established its status and asserted its correctness.

On the basis of the experience of Jesuit missionaries in China, till the beginning of the 17th century when they were sent to Vietnam to proclaim the Gospel, the clergy of this congregation also adopted the "missionary academic art" method to conquer the spiritual life of classes in Vietnamese society, especially the elite. However, in Vietnam and China, the form of expression and the degree of success, as well as the impact of this mission on the East-West cultural exchange process. in each country differed greatly.

In China, missionary academic methods were expressed in various forms. In order to infiltrate upper society and spread Christianity to the emperor, prince, noble and class of mandarins, Jesuits had to utilize many methods, such as acquaintances and those previously linked with Chinese mandarins, to establish new relations with other high-ranking mandarins [11, p. 231; 12; p. 125], or serve the mandarins in terms of technology, art [13, p.182], or with Chinese writers to discuss, exchanging, giving poems, visiting houses, giving gifts, etc. Meanwhile, in Vietnam, the method of association of Western clergies with the class of mandarins was not as rich as in China. The missionaries mainly used three methods, namely through and taking advantage of their relationships with officials and relatives to attract others to join the religion, to visit and provide gifts, and working together with the heads of other religions (Buddhism, Taoism) and the Confucian intellectuals. These methods were very popular in the early stages of Christianity entering the CochinChina and the Tonkin.

Understanding that Chinese and Vietnamese kings were very curious with Western items such as prisms, self-ringing watches, the piano, and oil paintings, the Jesuits often used these Western "wonders" $[1, \text { p. } 76-77]^{6}$ as gifts when visiting the emperor or a special area controlled by a mandarin. However, in both Vietnam and China, this measure also had different expressions and effects. In terms of categories, in China the gifts offered by clergies were very diverse and abundant. In 1601, when he entered to meet the Emperor Wan Li (万历), Matteo Ricci brought 34 European items of 15 different categories to offer $[14$, p. 20]. Meanwhile, because Vietnam was far from the Macao mission center and Portuguese merchants only came here a few times a year, sometimes there was no trading for several few years, the quantity items that missionaries brought with them or were small. Based on some records of contemporary Jesuits, it is possible to discern what types of products were often used by Jesuits in Vietnam as gifts - watches, pearls, gold, and Western science books [15, p. 105; 16, p. 113, 155; 17, p. 94]. As a result in China, the gifting of European items was one of the important measures to help Jesuits join and establish good relations with the dominant intellectuals in society, to gain permission from the authorities to stay in the country, and build churches and develop missions. Although kings and mandarins in Vietnam were very fond of Western gifts, the political context of the Trinh \& Nguyen dynasty in the 16 th and 17 th centuries resulted $[18, \text { p. 335-362; 19, p. 291-352] }]^{7}$

${ }^{6}$ In the eyes of Chinese and Vietnamese in the $16^{\text {th }}$ and $17^{\text {th }}$ centuries, items of Western origin, especially products related to science and technology, such as watches, lenses, and telescopes were strange items that resulted in curiosity. As a result these objects can be referred to as a "wonder" [1, p. 76-77].

${ }^{7}$ The $16^{\text {th }}$ and $17^{\text {th }}$ centuries were a volatile period in Vietnamese history. From 1527 to 1592 the Southern - Northern Dynasty war took place between the Mac family in Thang Long (North Dynasty) 
in the government of Cochin China and Tonkin needing weapons and ammunition more than gifts. No matter how many gifts the missionaries offered, even if the Portuguese merchant had not docked for a long time or came but did not bring what the kings needed, the preacher would be deported, Christianity would be banned. In fact, in Vietnam, the practice of providing Western items did not as effectively. Gifts were merely a means of communicating, debuting among clergies with contemporary rulers, but they were not an important measure to promote the development of the mission unlike in China.

In addition, in Vietnam and China, Jesuit missionaries used the method of "missionary bibliography" (书籍传教), i.e., the missionaries conducted the compilation or translation of some religious related books to God or Western technology and culture to serve their missionary process. However, in the two countries this practice of Jesuit missionaries also had differences in expression and effectiveness. For the most part, Jesuit missionary books in China had been written or translated in greater numbers and richer content than in Vietnam. At the end of the Minh Dynasty and early Thanh Dynasty, Jesuits compiled and translated 437 books, including 251 books on religion (Christianity) (57\%), 55 books on human sciences (13\%) and 131 books on science and technology (30\%) [20, p. 177-178]. Among the books were Western theology, Christian doctrine and technical science which had a great influence on the spread of Christianity in contemporary China. In fact, the process of compiling and translating a large number of contemporary scripts and documents, apart from the works of some Jesuits, included the contribution of certain Chinese writers and clergies. They played a key role in correcting and editing the works and translations by missioners. In particular, this force joined the current Jesuits in compiling and translating the scripts and documents. Typically, in the field of mathematics, there were Jǔhé yuánběn (幾何 原本), Cèliáng făyì (測 量 法 義) by Xu Guang Qi (徐光 啟) and Matteo Ricci (Chinese name was Li Ma Dou — 利瑪竇), Yuán róng jiào yì (圓 容 較 義), Tóngwén suàn zhǐ (同 文 算 指) by Li Zhi Zao (李 之 藻) and Matteo Ricci; in the astronomical field there were Hún gài tōngxiàn túshuō (渾蓋通憲圖說), Qiánkūn tǐ yì (乾坤 體 義) by Li Zhi Zao and Matteo Ricci, Jiănpíng yí shuō (簡 平 儀 說) by Xu Guang Qi and Sabatinode Ursis (Chinese name was Xiong San Ba 一 熊 三 拔).

Meanwhile, in the early $17^{\text {th }}$ century during Vietnam's mission, Jesuit missionaries brought and used two books in Chinese characters by missioners Matteo Ricci and Michele Ruggleri [11, p. 23-30] (Chinese name Luo Ming Jian — 羅明堅) compiled in

and the Le family in Thanh Hoa (Southern Dynasty). In the $17^{\text {th }}$ century, Vietnam continued to face war from the Trinh \& Nguyen dynasties. Specifically, from 1627 to 1672, the Trinh family in the North and the Nguyen family in the South fought 7 times, without a victory. After 46 years of constant fighting, both sides were exhausted physically and monetarily, so they had to accept a truce, a long-term separation. The Gianh river, known in history books as the Linh Giang, became the boundary that divided Dai Viet into two areas: from the Linh Giang river to the South called Dang Trong (CochinChina) under the control of Lord Nguyen. From the Linh Giang river to the South was called Dang Ngoai (Tonkin) under the management of King Le and Lord Trinh. This situation lasted until the end of the 18th century when the Tay Son peasant movement broke out (1771), in turn it destroyed the Nguyen Lord in CochinChina (1777) and Lord Trinh in Tonkin (1786) [18, p.335-362; 19, p. 291-352].

${ }^{8}$ Michele Ruggleri (1543-1607) - Chinese name Luo Ming Jian (羅明堅), was a Western missionary who worked in China at the end of the $16^{\text {th }}$ century and in the early $17^{\text {th }}$ century, born in Naples (Italy). In 1572, he joined the Jesuits. In 1578, he and several other Jesuit missionaries, Rudolph Acquaviva, Francesco Pasio, Matteo Ricci, and Nicolas Spinola, boarded a train in Lisbon to begin missionary missions in the Far East. In 1579, he was sent to China to evangelize, to Macao on July $22^{\text {nd }}$ of that year and began studying Chinese with a Chinese teacher. During the period of 1580-1583, he used to follow Portugese merchants to Guangzhou three times, learning indigenous languages and cultures, and finding ways to approach local 
China, it was Tiānzhǔ shí yì (天主 實 義) and Tiānzhǔ shèngjiào shílù (天主聖教實錄) [21, p. 114]. Later, in order to expand the Christian influence on the classes in Vietnamese society, especially the intellectuals, some clergies such as Amaral, Barbosa, Fontes, Borges, and Majorica interpreted and translated a number of documents, primarily Christian books, theology, history, and Christian rituals [21, p. 114-115] $]^{9}$. The Western clergies did not pay attention to books on science and the humanities. In linguistic terms, the contemporary Alexandre de Rhodes used the Vietnamese script $[22 ; 23]^{10}$ for Cathechism in octo dies diuisus. Meanwhile, a number of other Jesuits, typically Majorica, used Nôm $[24]^{11}$ to compile and translate some biblical references to Christianity [25, p. 53; 26, p. 23; 27, p. 161-162, 458 ${ }^{12}$. However, according to researchers at that time, learning and using Nôm proficiency for the clergy was not an easy task. Therefore, missionaries may only explain the content of Western materials, after which Vietnamese Confucianists mastered Nom script to help them record the materials [21, p. 114-115]. As for cooperation in compiling or translating materials in different scientific fields between Vietnamese intellectuals and Jesuit missionaries like in China, it is not mentioned in any materials.

The difference in the application of the "missionary academic" method by Jesuits in China and Vietnam profoundly affected the East-West cultural exchange process of the two countries during the $16^{\text {th }}$ and $17^{\text {th }}$ centuries. In China, the two-way impact of this process was quite evident and clear. In fact, along with the thorough application of the Jesuit's "missionary academic" method, many achievements of Western civilization such as academic thought, science and technology and many other fields such as astronomy, geography, mathematics, physics, chemistry, and military army... were introduced into

mandarins to promote the mission. He joined Matteo Ricci and a number of other Jesuits to flexibly and creatively adapt to the indigenous cultural adaptation strategy and make the mission in China much more successful in the later stages of the 16th century and in the early $17^{\text {th }}$ century [11, p. 23-30].

${ }^{9}$ In the early $17^{\text {th }}$ century, only a few years after arriving in Cochin China, the Jesuits immediately composed a book of catechism in Nôm to serve the mission. Later, with the aim of providing catechism books to the parishioners, Alexandre de Rhodes, Amaral, Fontes, Borges, Barbosa, composed or translated some Christian books. In particular, the number of books translated and edited by Majorica comprised 48 volumes [21, p. 114-115]

10 The Vietnamese alphabet was the name of a writing system created by missionaries in Vietnam in the first half of the $17^{\text {th }}$ century. It was based on the use of the Latin alphabet for phonetic transcription of Vietnamese. When it was developed, the script was mainly used by missionaries to compile dictionaries, catechism books and written reports and letters. At the same time, the Vietnamese still mainly used Chinese characters and Nôm characters. It was not until the end of the $19^{\text {th }}$ century and in the early $20^{\text {th }}$ century, when the Western trend in Vietnam exploded, that many National Scripts literary newspapers were born and this type of writing gained popularity by the people. In 1945, the Government of the Democratic Republic of Vietnam decided to choose National Scripts as the official writing system of Vietnam [22; 23].

${ }^{11}$ Chữ Nôm is a kind of figurative writing created by Vietnamese people based on the use of Chinese characters to write Chinese-Vietnamese words as well as Vietnamese pure words. To this day, there are still many different opinions about ancient literature of Vietnam around the origin and appearance of this type of writing. However, based on the source of epitaphs, it can be affirmed that the use of chũ Nôm can be recorded as early as possible, starting with the Ly dynasty (the $12^{\text {th }}$ century). Since then, until the $18^{\text {th }}$ to $19^{\text {th }}$ century, the Nôm script was used more often especially in the field of literature. This resulted in many famous works, the most typical was the Story of Kieu by Nguyen Du. By the end of the 19th century, under the rule of the French colonial government, the usage of Nom began to decline [24].

12 Girolamo Majorica was born in 1591 in Naples, Italy and died in 1656, in Thanh Hoa, Vietnam. In 1605, he joined the Jesuits. In 1624, he went to mission in CochinChina, Vietnam. Later, in 1631, he was sent to Tonkin (Tonkin) Vietnam to evangelize. During his time in CochinChina (1631-1634), with the help of Vietnamese intellectuals, he compiled 48 Christian-related books in Nom script, currently kept at the National Library of France [25, p. 53; 26, p. 23; 27, p. 161-162, 458]. 
this country in turn [1, p. 75]. At the same time, through the Jesuit missionaries' introduction and translation of many books of the classics, ideological and material achievements, including the model of China's political regime were also transmitted to the West [28, p. 118]. Meanwhile, in Vietnam, the role of Jesuits for East-West cultural exchange was not as prominent as in China. Although at that time, the process of cultural exchange between Vietnam and the West was still two-way, but in fact the introduction of Western civilization's achievements (academic, technical science) into Vietnam through Jesuit missionaries was not overly effective and comprehensive. It was limited to some areas, such as astronomy, mathematics, and medicine $\left[29\right.$, p. 297 ${ }^{13}$. Works and documents which were written or translated by contemporary Jesuits in order to introduce the cultural and historical aspects of Vietnam to the West, were in fact not a great amount [30, p.1-111; 31 , p. 62-66, 81-90; 32, p. 331-408, 517-552] ${ }^{14}$. Therefore, the expressions and achievements of the East-West cultural exchange process were closely linked to the role of Jesuits in Vietnam and were not truly impressive nor profound.

\section{The cultural integration of Jesuits missionaries in China and Vietnam}

From the second half of the $16^{\text {th }}$ century to the early $17^{\text {th }}$ century, Christianity was in turn introduced into China and Vietnam. This was a long process which was expressed through the transformation of the attitudes of the two countries' social classes refusing to accept this religion and paralleling with the process of gradually adapting to indigenous culture by Jesuits. However, in the process of accepting indigenous cultural values in China and Vietnam, not all missionaries of this congregation had a progressive and open perspective. At the same time, the attitude of missioners to the culture of the two countries, especially rituals, always resulted division and discontent. This resulted in a diverse picture of the cultural integration process of Jesuit missionaries in China and Vietnam.

The process of adapting to the indigenous culture by Jesuits in the two countries China and Vietnam was different, expressed at many levels and aspects. The second half of the 16th century, the Macao mission center was developed (1576) and oversaw the preaching of the Gospel in three countries - China, Japan, and Vietnam. In order to set foot on these three missionary lands, Jesuit missionaries had to go to Macao first and be assigned by the head of the archdiocese. Therefore, missionaries from different congregations, especially the Jesuits, were acutely aware of the meaning and value of "adaptation to indigenous culture" by Alessandro Valignano (his Chinese name was Fan Li An 一 范礼安). At that time, because it became clear that mastery of the missionary language was one of the prerequisites for preaching the Gospel to the people here, as well as the universal key to "Christianization" of the eastern countries, Jesuits missionaries in China and Vietnam were very focused on learning the native language. This was done in China in a methodical

${ }^{13}$ From the beginning of the $17^{\text {th }}$ century, Jesuit missionaries sought to approach the Nguyen Lord in CochinChina in Vietnam mainly by understanding their astronomy and healing abilities. By the end of the $17^{\text {th }}$ century, Jesuit missionary material recorded the case of the Jesuit Barthelemy Acosta (Portuguese) and Antoine Arnedo (Spainish) who worked as a physician and mathematician with the Nguyen lords [29, p.297].

${ }^{14}$ In the first half of the $17^{\text {th }}$ century, the contents of Vietnamese history and culture were recorded and sent to Rome by the Jesuits, or published in Europe in small quantities, mostly found in two works Divers Voyages et Missions, Histoire du Royaume de Tunquin of Alexandre de Rhodes and some letters and reports of contemporary Jesuits [30, p. 1-111; 31, p. 62-66, 81-90; 32, p.331-408, 517-552]. 
and thoughtful manner. From the end of the $16^{\text {th }}$ century, Michele Ruggieri, Matteo Ricci and a series of other Jesuit missionaries before entering the Chinese missionary mainland, used some other combined methods with the help of Chinese teachers, such as Western memorization techniques, analysis of Chinese characters or the use of the Chinese Latin alphabet [33, p. 226-227] to learn languages and study Chinese cultural history. Through this very serious study and research process, especially the continuous enrichment of the Chinese capital during the evangelization in different lands in domestic China, the Jesuit missionaries who could speak Chinese fluently also equipped themselves with an in-depth understanding of Chinese customs, and rituals through their own experience, practical notes, and access to bibliographies and books. This helped the Jesuits to create a deep impression on both the elite and the popular classes in Chinese society, thereby producing extremely favorable premises for the expansion and spread of Christianity in this country.

In stark contrast to the situation in China during the same period, Jesuit missionaries before the mission to CochinChina in Vietnam were not allowed to learn the Vietnamese language and culture in Macao. This process only started when they arrived to the mission and it originated from their personal awareness and needs, not the policy of the archdiocese of Macao. Due to the lack of preparation in the early $17^{\text {th }}$ century, the number of Jesuit missionaries who were fluent in Vietnamese was relatively small. During this period, the first missionaries of Christianity at Cochin China, such as Francesco Buzomi $[31, \text { p. } 67-70 ; 34, \text { p. } 24]^{15}$ had to use an interpreter to proclaim the Gospel to the natives. As a result, the missionary work was not highly effective [31, p. 72]. In Vietnam (CochinChina) at that time, Francisco de Pina [34, p. 26-27; 35, p. 834] ${ }^{16}$ was the only missionary who mastered the Vietnamese language and could directly preach to the people without an interpreter [34, p. 22]. Pina had also repeatedly criticized the missionaries for not working hard in the native language and considered it one of the leading causes of Christianity's failure to take root in the spiritual life of the country's inhabitants [35, p.36]. Then, with the help of him and some Vietnamese, Jesuit missionaries, most notably Alexandre de Rhodes [22, p. 106] ${ }^{17}$ quickly learned Vietnamese [31, p.73]. Over 50 years (1615-1665)

${ }^{15}$ Francesco Buzomi was considered the first founder of Christianity in CochinChina, Vietnam. He was born in 1576 in Naples (Italy), served as a missionary in Japan, and he was a professor of theology in Macao before arriving in CochinChina of Vietnam in 1615. He worked in CochinChina for 24 years (16151639), his missionary career in the first 10 years (1615-1624) was relatively favorable, while the later 14 years (1625-1639) were full of difficulties and challenges. In 1639, Lord Nguyen Phuc Lan (CochinChina) asked him to go to Macao to finish the work of spreading the Gospel. As a result, he became ill and died in Macao this year [31, p. $67-70 ; 34$, p. 24].

${ }^{16}$ Francisco de Pina is noted by the $17^{\text {th }}$ century missionary materials in Vietnam of the Jesuits as the first European missionary to master Vietnamese. He was born in 1585 in Portugal and travelled to CochinChina in Vietnam in 1617. When he first arrived, he lived in Hoi An (Quang Nam). In 1618, Pina joined two missionaries Francesco Buzomi and Christoforo Borri to Saltwater (Binh Dinh). Two years later (1620), he returned to Hoi An and in 1623, he came to live in Thanh Chiem, the palace capital of Quang Nam at that time. On December 15, 1625, while travelling with a Vietnamese man to reach a Portuguese ship anchored off the coast of Quang Nam to get some supplies, his boat was overturned when he reached the shore. The windstorm caused him to drown. People picked up his body and brought him to Hoi An and performed a solemn ceremony of morning [22, p. 26-27; 34, p. 834].

17 Alexandre de Rhodes was born on March $15^{\text {th }}, 1593$ in Avignon in a Jewish family. On April $14^{\text {th }}$, 1612, he joined the Jesuits in Rome, and in 1618 he was ordained a priest. Later this year he was accepted by the Jesuits who allowed him to go on a mission in East Asia three times after he had applied for travel between 1614 and 1618. He went to the Portuguese capital to board a ship to East Asia, but he had to stop for quite some time in Goa, so it was not until May $29^{\text {th }}, 1623$ that he arrived in Macao. Initially, he planned to travel to Japan for missionary work, but he was unsuccessful and was sent to Vietnam. He came 
laid the foundation for the development of Christianity in CochinChina, until the end of the $17^{\text {th }}$ century, when the mission on this land was chaired by Jesuits. With great results, at this time, the Vietnamese study of the new missioners who were highly regarded by the Superior in Macao. Before coming to Vietnam to mission, missionaries were able to study and foster Vietnamese language and study Vietnamese culture [21, p. 109].

In addition to learn indigenous languages, to facilitate the coming clergy classes to quickly acquire the language, writing, and culture of the two Vietnamese and Chinese peoples, Jesuits missionaries at both both countries compiled the European and native language dictionaries. In China, two bilingual dictionaries were written by the Jesuits at the end of the $16^{\text {th }}$ century. The first was a Portuguese-Chinese dictionary (Dicionário Português-Chinê) $[36, \text { p. 167, 169 }]^{18}$ by Michele Ruggieri and Matteo Ricci and the second was a Chinese-Portuguese dictionary (Dicionário Chinês-Português) [5, p. 286-287; 36, p. 167, 169 $]^{19}$ composed by Matteo Ricci and some contemporary Chinese intellectuals. The creation of these two dictionaries were significant. In addition to the religious aspect, the dictionary also recorded words and expressions from other fields associated with everyday life such as maritime, commerce, law, military, nautical, occupation, disease, cuisine [37, p. 2-10], and humidity. In fact, it was not only useful for the proclamation of the Gospel to the social strata of missionaries, but it also facilitated their understanding of cultural history as well as assisted them in integrating into the ordinary life of Chinese people. The two dictionaries were all compiled with a relatively scientific method. Therefore, the Dominican Order of priests operating in China and involved in the process of compiling and editing their congregation dictionaries had to refer to this method, paying special attention to sound annotation by Matteo Ricci and the Jesuits.

Meanwhile in Vietnam, the process of indigenous dictionary compilation by the Jesuits occurred half a century later than in China. It was not until the first half of the $17^{\text {th }}$ century that knowledge of the Vietnamese language became an urgent requirement for Jesuits serving in the country. The study of the language was based on two Vietnamese-Portuguese-Latin dictionaries (Diccionário Anamita-Português-Latim) of Gaspar

to CochinChina Vietnam for the first time in December 1624 and by July 1626 he returned to Macao to prepare for Tonkin (Vietnam). On March $19^{\text {th }}, 1627$, he arrived in Tonkin and in May 1630 he was exiled from the area. From 1630 to 1640, he taught theology at the academy Madre de Deus. From 1640 to 1645 he returned to the mission in CochinChina. In July 1645, he left CochinChina to Macau and went to Europe. In 1654 he travelled to Persia and died at Ispahan on November 5, 1660 [22, p. 106].

${ }^{18}$ From 1560 onwards, in order to realize China's "Christianization" goal, Jesuit missionaries went to Macao in turn to learn the language and learn indigenous culture. For this work, two missionaries Michele Ruggieri and Matteo Ricci compiled the Portuguese-Chinese dictionary (Dicionário Português-Chinês) between 1583 and 1588. Handwritten manuscripts of this dictionary were stored in the Jesuit archives in Rome for over 300 years and it was not until 1934 that Pasquale D'Elia discovered it. This dictionary has more than 6,000 words, arranged in order from A to Z in the Portuguese alphabet; the composition was divided into four columns. The first column was Portuguese words, the other three columns in the order of Latin, Chinese and Italian words respectively [36, p. 167, 169].

19 At the end of the $16^{\text {th }}$ century, in addition to the Sino-Chinese Dictionary (Dicionário PortuguêsChinês) and the process of evangelization in China, the missionaries Matteo Ricci, Lazzaro Cattane also collaborated with Chinese people to compile the Dictionary Chinese - Portugese (Dicionário ChinêsPortuguês), which mentioned the notes of Matteo Ricci and the contemporary missionaries. When compiling this dictionary, the clergies had agreed upon the way of using the Chinese phonetic Latin alphabet. Unfortunately, scholars have been unable to find the original dictionary [5, p. 286-287; 36, p. 167, 169]. 
d'Amaral [38, p. 8, 291] $]^{20}$ and Diccionário Português-Anamita by Antonio Barbosa [39, p. 214-215] ${ }^{21}$ who also acquired his own Vietnamese vocabulary. The Jesuit missionary Alexandre de Rhodes compiled the Vietnamese-Portuguese-Latin dictionary (Dictionarium Annamiticum Lusitanum et Latinum) and it was published in Rome in 1651, consisting of a translation of about 8000 Vietnamese - English and Latin words along with an extended summary of Vietnamese grammar and contemporary pronunciation [30, p. 1-2, 491]. It can be said that, in addition to historical value, the creation of this dictionary was also an important milestone in shaping the Vietnamese national letters [40, p. 54].

Strategies for adapting to the indigenous culture, applied by Jesuit missionaries, were not only different in terms and levels of expression, but also in the specific application process. If in Vietnam, the adaptation to the indigenous culture by the Jesuits was mainly expressed in terms of language learning and understanding of Vietnamese history and culture, then in China, in addition to the field mentioned above, the adaptation to indigenous culture by Jesuit missionaries was also expressed more diversely, more radical, and more profound in other ways. Among them was the event of the missionary Matteo Ricci for twice "changed clothes" - the first time in 1583 from the monastic clothes of Christianity changing to the Buddhist clothes and the second in 1595 from the Buddhist clothes changing to the Confucian dress was one of the typical phenomena. This reflected the thoroughness and creativity of the Jesuit missionaries in China in the usage of the strategies adopted by Alessandro Valignano's native culture adaptation that were aimed at solving the harmonious relations between the Christianity that missionaries were spreading in China and the indigenous religion and culture. In fact, in order to achieve satisfactory results in missionary work, Jesuit missionaries had to deeply integrate into Chinese culture, openly embrace the values of the country's culture. This was the secret success of Matteo Ricci and Jesuits in contemporary China. Therefore, although "changing clothes" was only a change of the outside form, however, it could not be considered merely a phenomenon of changing clothes, but it must be seen that it was a reflection of the adaptive and dialectical features in the way of Christian propaganda by Matteo Ricci and Jesuits in China [41, p. 55].

Furthermore, in order to make the Chinese lieutenant class accept Christianity, the Jesuits were represented by Matteo Ricci, there was research conducted in Confucianism - the mainstream culture in Chinese society at that time. The process of dealing with the relationship between Christianity and Confucianism resulted in the concepts of

${ }^{20}$ Gaspar d'Amaral, born in 1592 and died in 1645 or 1646, was a Portuguese Jesuit, born in Corvaceira, the diocese of Viseu, Portugal. He entered the Jesuits in 1608 and was then taught Latin in Braga, Coimbra and Évora. In 1623, he took the Jesuit mission to India and then through Macao. In November 1629, he arrived in Tonkin (Tonkin), Vietnam. During his seven-year missionary years (1629-1636), he baptized over 40,000 Tonkin people (Tonkin). Also, in the process he learned Vietnamese fluently. He was the author of the Diccionário anamita-português-latim, later recognized by Dac Lo and serving as a basis for compiling the Vietnamese-Portugese-Latin Dictionary (Dictionarium Annamiticum Lusitanum et Latinum) in $1651[38$, p. 8, 291].

${ }^{21}$ Antonio Barbosa (1594-1647), born at Arrifana de Souza, Portugal, joined the Jesuits on March 13, 1624. At the end of April 1636, he went to Tonkin, but returned to Macao in May 1642 for health reasons. In Macao, his health condition did not improve. In 1647, he traveled from Macao to Goa to recover and died on the journey before he could set foot in Goa. Antonio Barbosa is the editor of the Portuguese-Vietnamese dictionary (Diccionário Português-Anamita). Later, Alexandre de Rhodes relied on it to compose his dictionary [39, p. 214-215]. 
“Bǔ rú” (补 儒), “Hé rū” (合 儒) [1, p. 77; 42, p. 255] 22 that on the one hand receiving the essence of Confucian - Meng Zi doctrine, on the other hand, explaining and adjusting the Christian doctrine to promoting the meeting and the similarities between Confucianism and Christianity. This was another unique point in the process of applying the cultural adaptation strategy of Matteo Ricci and the Jesuits.

Although there was a Jesuit missioner who changed Vietnam's traditional Tonkin [35, p. 104-105] ${ }^{23}$ restoration, this phenomenon was not yet able to clearly define the process for applying the cultural adaptation strategy, which was perhaps merely a measure to achieve the long-term goal of staying in Vietnam and avoiding the skepticism of the local authorities for their sneaky missionary actions. In the early stages of Christianity's spead in Vietnam (half of the $17^{\text {th }}$ century), there was no record of how Jesuits sought to integrate the relationship between Confucianism and Christian doctrine as in China. The Jesuits often argued with Confucian scholars and other religions [43, p.71-72] to prove the superiority of the Christian doctrine. Based on some records of the Jesuit missionaries in Vietnam in the $17^{\text {th }}$ century, it is apparent that they repeatedly achieved victories in those debates to entice followers of other religions to believe in Christianity and see it as one of the effective measures for spreading the Gospel in Vietnam. However, in consideration of the adaptation to indigenous culture as well as comparing the success of Matteo Ricci and the Jesuits to China, this practice of the Jesuits in Vietnam was indeed still not the most optimal solution to bring success to the current East-West mission and cultural exchange.

From the end of the $16^{\text {th }}$ century to the beginning of the $17^{\text {th }}$ century, Christianity was received in turn by Chinese and Vietnamese societies. This demonstrated that the strategy of indigenous culture adaptation of the Jesuits was, to a certain extent, effective. However, that process did not encounter any objective or subjective obstacles, but in the early Jesuit missions in China and Vietnam, there was much debate about many rituals in the two countries' culture, especially worship. At the time, the debate of Jesuit missionaries mainly focused on a number of issues, such as ancestor worship and Confucian worship. That debate led to a division within the Jesuits in China and Vietnam. A part of the Jesuits, who advocated "a good attitude of tolerance and preservation of traditional practices" [44, p.38-39], proposed and supported the creative and flexible use of cultural adaptation strategies. They argued that ancestor worship and Confucianism of the indigenous people were merely an act of expressing remembrance for the ancestors and reverence to Confucian civilians, they were not at all superstitious or vindictive. It had nothing to do with Christian doctrine, so believers should be allowed to keep this ceremony [44, p. 67].

22 “Complementary Confucianism (补 儒 Bǔ rú)" and "Matching Confucianism (合 儒 Hé rú)" was a progressive perspective proposed by Jesuit priest Matteo Ricci in the process of evangelization in China. It endeavored to combine, supplement, religious thought, Western philosophy, and Christianity as the representative of the inherent Chinese traditional religious thought and traditional philosophy where Confucianism was entrusted [42, p.255]. According to scholar Shi Jing Huan, the viewpoint of “Complementary Confucianism (补 儒 Bŭ rú)", the Jesuit's “Combining Confucianism (合 儒 Hé rú)" in China at the end of the $16^{\text {th }}$ century and early the $17^{\text {th }}$ century was expressed in two respects, one in the process of evangelization, many Confucian texts were used to prove the absence of contradiction between the Christian doctrine and the doctrine of Confucianism. Secondly, Confucian doctrine was matched with Christian doctrine to show that the Christian doctrine is more complete than the Confucian theory, which can complement the parts of Confucian swordsmanship [1, p.77].

${ }^{23}$ In the years 1631-1632, during the mission in Tonkin Vietnam, two Jesuits Gaspar d'Amaral and Antonio Fontes removed the monk's religious attire to change their clothes. The court of King Le-Trinh Lord in Tonkin at that time and every day joined the court with officials [35, p. 104-105]. 
In China, Jesuits supported this view including Matteo Ricci, Michele Ruggieri, P. Jean Soerio, P. Lazare Cattaneo, Diego de Pantoja, Alfonso Vagnoni, P. Alvare de Semedo, and Jules Aleni [44, p. 66-67]. In Vietnam, by the beginning of the $17^{\text {th }}$ century, when Francesco Buzomi arrived in Cochinchina (CochinChina) for missionary, perhaps he had been influenced by Matteo Ricci and the missionaries in China for half a century. The missionaries of the precincts of CochinChina also advocated for allowing Catholics to perform rituals such as worshiping the deceased, burning incense, setting up outdoor incense and worshiping [45, p. 121].

In fact, this open and progressive missionary strategy helped the Jesuits in the two counties of China and Vietnam to achieve initial success. However, from the beginning they were also subjected to attacks and protests from a conservative, narrow-minded Jesuit missionary. Among them were the Jesuits of Francisco de Pina, P. Marquez, Alexandre de Rhodes in Vietnam and Nicolas Longobardi, Sabatinode Ursis, Francesco Sambiasi, and P. Jean Rodriguez [46, p. 67-68] in China as typical figures. In a letter sent from CochinChina, Vietnam on July $3^{\text {rd }}, 1626$, missionary Francesco Buzomi complained about the narrow-minded attitude of two Francisco de missionaries such as Pina and P. Marquez in adapting to the indigenous culture [47, p. 190]. In particular, the missioner Alexandre de Rhodes expressed a non-cultural, non-historical point of view in the evangelization process in Vietnam. He always had a critical attitude against religious practice, royal sacrifice, worship of ancestors and kamma. He regarded it as superstitious work [43, p. 113-114]. Meanwhile, in China at that time, some Jesuits who opposed Matteo Ricci's missionary strategies, such as Nicolas Longobardi, said that ancestor worship and Confucian worship were not related to worshiping the statue, contrary to the Christian doctrine. Therefore, it must be strictly prohibited [45, p.67].

Thus, in the early $17^{\text {th }}$ century, within the Jesuit missionaries in China and Vietnam, there existed a mixed opinion on how to deal with traditional rituals in the two countries. This resulted in arguement and division. If it was not timely prevented, this situation could have had a negative effect on the Jesuit missionary career in each country. Therefore, in China, in the first half of the $17^{\text {th }}$ century, missioners at the Far East P. Jér Rodriguez and Chinese provinces P.André Palmeiro twice convened conferences in 1621 and 1627 in an effort to reconcile internal conflicts among Jesuits missionaries in China [45, p.68]. Despite this, the struggle and schism within the Jesuits in China continued to exist and became an excuse for clergies in other congregations to attack the Jesuits, which resulted in the explosion of "Chinese rituals controversy" in the first half of the $18^{\text {th }}$ century. Meanwhile, in Vietnam, within 10 years of Jesuit missionaries first arriving in Vietnam (CochinChina), an internal debate of great proportion on the issue of indigenous rituals also took place. Hence, at the end of 1624, Jesuit missionary Gabriel de Mattos, the abbot of St. Paul's College, Macao, went to CochinChina to investigate and examine the missionary situation, but in fact, he went to resolve disputes within the Jesuit missionaries in this area. However, he could not achieve the desired results [48, p. 111]. In Vietnam from the end of the $17^{\text {th }}$ century to the early $18^{\text {th }}$ century, Jesuit missionaries who supported the indigenous cultural adaptation strategy, no longer prevailed as in the previous period. As a result, after the "Chinese ritual debate" between the Dominican Order and Missions étrangères de Paris with the view of opposing the Eastern rituals, the Pope publicly implemented strict orders forbidding "Chinese rituals" and did not encounter any resistance. It was not until the end of the $18^{\text {th }}$ century when the bishop of Pigneau de Béhaine [49, 
p. $7-10]^{24}$ tried to make the rulers of the Nguyen dynasty adhere to the religion and as a result, the problem of adaptation to the indigenous culture as well as the debate about rituals was renewed. It led to a relatively fierce reaction from the leading forces of the current Vietnamese monarchy.

\section{Conclusion}

During the $16^{\text {th }}$ and $17^{\text {th }}$ centuries, despite being under the management of the Macao diocese, missionary Alessandro Valignano's strategy of adapting to the indigenous culture and applying the same method of evangelism was shared. However, due to the influence of many factors, the cause of spreading the Christianity of Jesuit missionaries in China and Vietnam differed in terms and degree of concrete expression as well as results. At the end of the $16^{\text {th }}$ century and in the early $17^{\text {th }}$ century, due to the Macao diocese holding a different view of the roles and the importance of each nation, it led to a renewal of evangelization as well as a number of Jesuits who operated in each country being afraid of significant differences. If from 1552 to 1583, up to 50 Western missionaries were sent to China, of which Jesuits missionaries made up half of them [13, p. 30], no clergy of this congregation set foot in Vietnam. This resulted in the evangelization work of Jesuits in Vietnam be more than half a century behind China. In addition, the active, flexible, and creative capability of applying the "missionary academic" method played an extremely important role as one of the significant factors that determined the level of success in Gospel missionary activities of Jesuits in China and Vietnam during this period. From missionary works in the $16^{\text {th }}$ and $17^{\text {th }}$ centuries in the two countries, Jesuit missionaries in China used academic and ideological achievements as well as science and technology of the West more comprehensively and more effectively to conquer the faith of social classes in this country, compared to Jesuit missionaries in Vietnam where only a few areas such as medicine, math, and astronomy were touched upon. In particular, in China from the end of the $16^{\text {th }}$ century to the first half of the $17^{\text {th }}$ century, there still existed disagreements in tactics and attitudes towards indigenous rituals among Jesuits. However, at that time, the Jesuit mission was still progressive and open-minded to the indigenous culture held by the representative, Matteo Ricci. Therefore, the indigenous cultural adaptation strategy was applied thoroughly and creatively. In the meantime, at the beginning of the $17^{\text {th }}$ century, when Jesuits missionaries came to Vietnam for missionary work, the debate on the issue of rituals within the Jesuit missionary in China had more or less affected the host.

${ }^{24}$ Pigneau de Béhaine was born on November 2, 1741 in the village of Origny, Aisne Province, in northern France. He attended the seminary of the Foreign Missionary Society of Paris. In 1765, he was ordained a priest and in 1766, he sailed to the CochinChina Vietnam missionary. In July 1767, Pigneau went to Can Cao (Ha Tien) to operate under the bishop of Piguel, who was overseeing the territory of Cochin China and becoming the Director of Hon Dat Seminary. However, in 1770, due to the unstable Ha Tien situation, Pigneau joined the Hon Dat seminary to Pondichéry (India). That same year, he was ordained a bishop of Adran. In March 1775, Pigneau returned to Ha Tien for a second time when Nguyen Anh a descendant of the Nguyen Lords in CochinChina, was being pursued aggressively by the Tay Son army. Pigneau decided to carry out a major plan that was to help Nguyen Anh return to the throne and convert Nguyen Anh and turn CochinChina into a French Christian nation. Since then, the life of this missionary has always been associated with the ups and downs of the Nguyen family, especially Nguyen Anh - the first King of the Nguyen dyn-asty - the last monarchy in Vietnamese history [49, p. 7-10]. 


\section{References}

1. Shi Jinghuan (1983), The missionary academic ways of Jesuits into China at the end of the first period of Qing Dynasty, Neimenggu shida xuebao, no. 3, pp. 73-78. (In Chinese)

2. Liu Yunhua (2003), The missionary academic strategy of Matteo Ricci and early missionaries and literary meaning, Tianjin shehui kexue, no. 6, pp. 130-135. (In Chinese)

3. Dunne, G.H. (1962), Generation of Giants: The Story of the Jesuits in China in the Last Decades of the Ming Dynasty, Notre Dame: University of Notre Dame Press.

4. Pei Huaxing and Xiao Ruihua (1938), Records of the spreading of Christianity in China in the $16^{\text {th }}$ century, Shanghai: Shangwu yin shuguan Publ. (In Chinese)

5. Li Madou, Jin Nige, He Gaoji, Wang Zunzhong and Li Shen (1983), Notes of Matteo Ricci in Chin, vol. 1, Beijing: Zhonghua shuju Publ. (In Chinese)

6. Morgan, J.F. (1993), The Japanese and the Jesuits: Alessandro Valignano in Sixteenth Century Japan, New York: Routledge.

7. O’Malley, J. W., Bailey, C. A., Harris, S. J. and Kennedy T. F. (1999), The Jesuits: Cultures, Sciences, and the Arts, 1540-1773, vol. 1, Toronto: University of Toronto Press.

8. Fontana, M. (2010), Matteo Ricci: A Jesuit in the Ming Court, Maryland: Rowman \& Littlefield.

9. Hasia, R. P. (2016), Matteo Ricci and the Catholic Mission to China, 1583-1610: A short history with document, Indianapolis: Hacketts.

10. Laven, M. (2011), Mission to China: Matteo Ricci and the Jesuit Encounter with the East, London: Faber \& Faber.

11. Fei Laizhi, Feng Chenggou (1995), Directory and storyline of Jesuits in China, vol. 1, Beijing: Zhonghua shuju Publ. (In Chinese)

12. Cui Weixiao (2006), Study of missionary activities of Franciscan clergy in China Ming Qing period (1579-1732), Beijing: Zhonghua shuju. (In Chinese)

13. Charles, E. R. and Bonnie, B.C. (1988), East Meets West: The Jeuits in China 1582-1773, Chicago: Loyola University Press.

14. Han Qi and Wu Min (2006), Xi chao chongzheng ji xi chao dingan (wai san zhong), Beijing: Zhonghua shuju Publ. (In Chinese)

15. Truong, B. C. (1999a), History of Catholic development in Vietnam, Nguyệt san Công giáo và Dân tộc, no. 51, pp. 90-128. (In Vietnamese)

16. Truong, B. C. (1999b), History of Catholic development in Vietnam, Nguyệt san Công giáo và Dân tộc, no. 52, pp. 110-128. (In Vietnamese)

17. Truong, B. C. (1999c), History of Catholic development in Vietnam, Nguyệt san Công giáo và Dân tộc, no. 53, pp. 86-128. (In Vietnamese)

18. Truong, H. Q, Dinh, X. L. and Le, M.H. (2006), General History of Vietnam, Hanoi: NXB Giáo dục Publ. (In Vietnamese)

19. Le, T.K. (2014), Vietnam History from the origin to the middle of the $20^{\text {th }}$ century, Hanoi: NXB Thế giới Publ. (In Vietnamese)

20. Qian Cunxun and Dai Wenbo (1986), Impact of bibliographic translation in modern times on Chinese modernization, Wenxian, no. 2, pp. 176-204. (In Chinese)

21. Truong, B. C. (1999d), History of Catholic development in Vietnam, Nguyệt san Công giáo và Dân tộc, no. 56, pp. 100-128. (In Vietnamese)

22. Do, Q. C. (1972), History of Vietnamese script (1620-1659), Saigon: NXB Tủ sách Ra Khơi Publ. (In Vietnamese)

23. People's Committee of Binh Dinh Province (2016), Binh Dinh with National Scripts, Ho Chi Minh: NXB Tổng Hợp thành phố Hồ Chí Minh Publ. (In Vietnamese)

24. Dao, D. A. (1975), Nôm Origin - Structure - Evolution, Hanoi: NXB Khoa học Xã hội Publ. (In Vietnamese)

25. Jacques, R. (2002), Portuguese pioneers of Vietnamese linguistics prior to 1650, Bangkok: Orchid Press.

26. Wynn, W. (2010), Vietnam and the West: New Approaches, New York: Cornell Southeast Asia Program.

27. Do, Q. C. (2008), Jesuit in Dai Viet society 1615-1773, Hanoi: NXB Tôn giáo Publ. (In Vietnamese)

28. Chen Hongyi (2001), Commentary on "East to West", Gongan daxue xuebao, no. 6, pp. 118-122. (In Chinese)

29. Montézon, F., Estève, E., Rhodes, A., Tissanier, J. and Saccano, M. (1858), Mission de la Cochinchine et du Tonkin avec gravure et carte géographique, Paris: Charles Douniol.

30. Rhodes, A. (1651), Histoire du Royaume de Tunquin, Lyon: Chez Iean Baptiste Devenet. 
31. Rhodes, A. (1653), Divers Voyages et Missions, Paris: Imprimeur ordinaire du Roy \& de la Reyne.

32. Cadière, L. (2003), Bulletin of Friends in the ancient capital of Hue, vol. 18, Hue: NXB Thuận Hóa Publ. (In Vietnamese)

33. Bian Haoyu (2009), Initial study of Chinese language learning method for missionaries to China during the Ming Qing period, Xueshu jiaoliu, no. 12, pp. 226-228. (In Chinese)

34. Bartoli, D. (1663), Dell' historia della Compagnia di Giesv La Cina (Terza parte), Rome: Nella Stamperia del Varefe.

35. Dror, O. and Taylor, K. W. (2006), Views of Seventeenth-century Vietnam: Christoforo Borri on Cochinchina and Samuel Baron on Tonkin, New York: Cornell Southeast Asia Program.

36. Yang Huiling (2011), The origin of Chinese and foreign bilingual dictionaries, Cishu yanjiu, no. 3, pp. 164-177. (In Chinese)

37. Yao, Xiaoping (2014), The Earlier Language and Cultural Contact between China and the West as Reflected in the Dicionário Português-Chinês, Dangdai waiyu yanjiu, no. 9, pp. 2-10. (In Chinese)

38. Zwartjes, O. (2011), Portugese Misionary Grammars in Asia, Africa and Brazil, 1550-1800, Amsterdam: John Benjamins Publishing Company.

39. Barbosa, M. D. (1741), Bibliotheca Lusitana, Historica, Critica e Cronologica, vol. 1, Lisboa: Na Officina Patriarcal de Francisco Luiz Ameno.

40. Thompson, L. C. (1987), A Vietnamese Reference Grammar, Honolulu: University of Hawaii Press.

41. Wang Zhiping (2011), On the Two Times of Matteo Ricci's Changing Clothes and It's Cultural Significance, Anqing shifan xueyuan xuebao, no. 3, pp. 51-55. (In Chinese)

42. Xie, X. J. (2015), A Collection of Essays on China: 1988-1989, Raleigh: Lulu Press.

43. Nguyen, H. (1959), Evangelical History in Vietnam, vol. 1, Saigon: NXB Hiện tại Publ. (In Vietnamese)

44. Zhu Dafeng (2009), Matteo Ricci Rules and the exchange of Chinese culture - the West at the end of Ming and Qing Dynasties, Lantai shijie, no. 4, pp. 38-39. (In Chinese)

45. Truong, B. C. (2000), History of Catholic development in Vietnam, Nguyệt san Công giáo và Dân tộc, no. 72 , pp. $104-128$.

46. Li Yuan (2014), A Study of the Jesuit Missionaries'Discussion on Chinese Sacrificial Rites during the Late Ming and Early Qing Period, Shanxi daxue xuebao (Zhexue shehui kexue ban), vol. 37, no. 5, pp. 62-72. (In Chinese)

47. Vu, K. T. (1956), Les missions jésuites avant les Missions étrangères au Viêt Nam, 1615-1665, Paris: Institut Catholique.

48. Truong, B. C. (1999e), History of Catholic development in Vietnam, Nguyệt san Công giáo và Dân tộc, no. 50, pp. 90-128.

49. Truong, B. C. (1992), The Catholic of CochinChina in the Episcopal Pigneau, Ho Chi Minh: Tủ sách Đại Kết Publ.

Received: March 21, 2019

Accepted: March 19, 2020

Authors' information:

Truong Anh Thuan — PhD, Professor; tathuan@udn.ued.vn

Nguyen Van Sang — Postgraduate Student; nvsang@udn.edu.vn

\section{Компаративный анализ миссионерского метода и интегративных подходов иезуитов: на материалах Китая и Вьетнама XVI-XVII вв.}

\section{Чьюнг Ань Тхуан, Нгуен Ван Шанг}

Университет Дананг, Университет науки и образования,

Вьетнам, 84-5113, Дананг, ул. Тон Дук Тханг, 459

Для цитирования: Truong Anh Thuan, Nguyen Van Sang. A comparison of the missionary method and cultural integration of Jesuits: A study in China and Vietnam during the $16^{\text {th }}$ and $17^{\text {th }}$ centuries // Вестник Санкт-Петербургского университета. Философия и конфликтология. 2020. Т. 36. Вып. 2. С. 407-421. https://doi.org/10.21638/spbu17.2020.216 
В конце XVI - начале XVII столетия иезуитская миссия под управлением епископа Макао активно действовала на территории Китая и Вьетнама: иезуиты несли знание о боге и проповедовали Евангелие, обращали в христианство жителей этих странах. Главной причиной успеха миссии стало использование соответствующих методов и принципов культурной интеграции применительно к конкретной каждой стране. Однако по причине различной парадигмы исторического развития в Китае и Вьетнаме и, в особенности, из-за разногласий среди самих иезуитов по поводу восприятия культурных традиций и отношений с представителями коренных народов, процесс евангелизации в этих странах происходил по-разному. Основываясь в своих научных исследованиях на исторических и логических методах, а также используя компаративный подход, авторы анализируют и сравнивают сходства и различия миссионерских методов, применявшихся на территориях Вьетнама и Китая, а также защищают идеи культурной интеграции в двух странах. В основу данной работы были положены первоисточники, архивные записи и недавно опубликованные результаты исследований ученых из Китая, Вьетнами и из других стран. Работа вносит вклад в изучение сходства и различия миссионерских методов и культурной интеграции, ее результаты могут быть использованы для дальнейшего изучения истории христианства в Китае и Вьетнаме в XVI-XVII вв.

Ключевые слова: Китай, Вьетнам, иезуиты, христианство, культурная интеграция.

Статья поступила в редакцию 21 марта 2019 г.; рекомендована в печать 19 марта 2020 г.

Контактная информация:

Чьюнг Ань Тхуан — канд. филос. наук, проф.; tathuan@udn.ued.vn

Нгуен Ван Шанг - аспирант; nvsang@udn.edu.vn 